\title{
Effect of Hypophysectomy and Growth Hormone Administration on Somatostatin and Gastrin Content in the Stomach of Rats
}

\author{
Junji KASANUKI, Hideichi MAKINO, YASUHisa MATSUSHIMA, \\ AZUMA KANATSUKA, MORIHIRo MIYAHIRA, \\ Yoshitaka TOKUMASA and AKIRA KUMAGAI \\ The Second Department of Internal Medicine, Chiba University \\ School of Medicine, Chiba 280, Japan
}

\begin{abstract}
The effect of hypophysectomy and bovine growth hormone (GH) administration on somatostatin (SRIF) content as well as gastrin content in the rat stomach was investigated. SRIF content was determined by a specific radioimmunoassay. The total SRIF content in the stomach had decreased 4 weeks after hypophysectomy but was restored significantly in those rats which were subjected to bovine GH administration for 7 days after hypophysectomy. Furthermore, in control rats, an increase in SRIF content in the stomach was observed after 7 days of GH administration. Similar changes in total content of gastrin were observed after hypophysectomy and bovine GH administration, although these changes were not significant. These results indicate that GH may influence gastric function through changes in SRIF and gastrin content in the stomach.
\end{abstract}

It has been reported by several workers (Arimura et al., 1975; Polak et al., 1975) that somatostatin which was first isolated from ovine hypothalamus exists throughout the gastrointestinal tract. Somatostatin strongly inhibits the secretion of gastrointestinal hormones (Bloom et al., 1974; Guenther et al., 1975) and gastric acid and pepsin (Albinus et al., 1977; Schrumpf et al., 1976). However, the functional role of somatostatin containing $\mathrm{D}$ cells of the gastrointestinal tract is not known. Recently it was reported that the secretion of gastric somatostatin was stimulated by exogenous gastrin administration (Barden et al., 1979), or by the intragastric administration of nutrients and $\mathrm{HCl}$ (Schusdziarra et al., 1978). On the other hand, it is well-known that GH influences gastrin content in the stomach (Creutzfeldt et al., 1971; Enochs et al., 1976), and gastric acid and pepsin secretion

Received October 18, 1980.
(Schapiro et al., 1970 ; Crean, 1963 ; Snapper et al., 1937; Jacobson and Magnani, 1964). Therefore, in order to clarify the relationship between GH and gastric function, the present study investigated the effect of hypophysectomy and GH administration on somatostatin and gastrin content in the stomach of rats.

\section{Materials and Methods}

Male Sprague-Dawley rats aged 7 weeks were used in the present study. The animals were maintained at $24^{\circ} \mathrm{C}$ under controlled lighting (lights on $0700 \mathrm{~h}-1700 \mathrm{~h}$ ) and given free access to laboratory feed (Oriental Yeast Co., Tokyo) and tap water throughout the experiments.

Six rats were hypophysectomized by the transpharyngeal technique (Institute of Animal Reproduction, Saitama). Three weeks after operation, these 6 rats and 7 control rats received injections of bovine growth hormone (NIH-GH-B18) subcutaneously at $500 \mu \mathrm{g} / \mathrm{day} / \mathrm{rat}$ for 7 days at the same time each day. Another group of 6 control and 6 hypophysectomized rats received injections of $0.2 \mathrm{ml}$ 
Table 1. Somatostatin Content in the Stomach of Hypophysectomized and Control Rats.

\begin{tabular}{lcccc}
\hline \hline & No. & ng/organ & ng/g wet weight & ng/g protein \\
\hline Control & 6 & $1060 \pm 69^{\mathrm{a}}$ & $1089 \pm 78$ & $6797 \pm 380$ \\
Hypox & 6 & $427 \pm 32^{\mathrm{b}}$ & $768 \pm 62^{\mathrm{c}}$ & $4948 \pm 487 \mathrm{c}$ \\
Hypox $+\mathrm{GH}$ & 6 & $748 \pm 133^{\mathrm{d}}$ & $1070 \pm 214$ & $9270 \pm 2660$ \\
Control+GH & 7 & $1590 \pm 149^{\mathrm{e}}$ & $1458 \pm 144^{\mathrm{f}}$ & $11480 \pm 1061 \mathrm{e}$ \\
\hline
\end{tabular}

a: mean \pm SEM.

b : $\mathrm{P}<0.001, \mathrm{c:} \quad \mathrm{P}<0.02$ compared to the control values.

$\mathrm{d}: \quad \mathbf{P}<0.05$ compared to the values for hypophysectomized rats.

e: $\mathrm{P}<0.01$, f: $\mathrm{P}<0.05$ compared to the control values.

Table 2. Body Weight, Stomach Weight, and Gastrin Content in Hypophysectomized and Control Rats.

\begin{tabular}{lcccc}
\hline \hline & No. & Body Weight & Stomach Weight \\
$(\mathrm{mg})$ & $\begin{array}{c}\text { Gastrin Content } \\
(\mathrm{ng} / \text { organ })\end{array}$ \\
\hline Control & 6 & $211 \pm 12.5^{\mathrm{a}}$ & $978 \pm 42.2$ & $137 \pm 18.4$ \\
Hypox & 6 & $102 \pm 4.8^{\mathrm{b}}$ & $550 \pm 16.7 \mathrm{~b}$ & $111 \pm 18.3$ \\
Hypox+GH & 6 & $135 \pm 1.8^{\mathrm{c}}$ & $708 \pm 15.3^{\mathrm{c}}$ & $152 \pm 15.1$ \\
Control+GH & 7 & $237 \pm 17.6$ & $1114 \pm 55.2$ & $178 \pm 32$ \\
\hline
\end{tabular}

a: mean \pm SEM.

b: $\mathbf{P}<0.001$ compared to the control values.

c: $\mathbf{P}<0.001$ compared to the values for hypophysectomized rats.

saline in the same manner. The animals were killed $24 \mathrm{~h}$ after the last injection. All animals were weighed and decapitated. The stomach was quickly resected and incised along the greater curvature, washed by chilled saline, weighed and homogenized in $10 \mathrm{ml}$ of chilled $2 \mathrm{~N}$ acetic acid. The extracts were suspended in boiling water for $10 \mathrm{~min}$, centrifuged at $12,000 \mathrm{rpm}$ for $30 \mathrm{~min}$, and a part of the supernatant was lyophilized and kept refrigerated. The rest of the supernatant was freezed until assay. SRIF was measured by specific radioimmunoassay, described elsewhere (Makino et al., 1977; and 1979), and gastrin was measured with a CIS gastrin kit (CEA-IRE-SORIN Association, Saclay).

\section{Results}

The sensitivity of the assay of SRIF was $7.8 \mathrm{pg} /$ tube and the displacement curve of the gastric extracts was found to be parallel to the standard curve (data not shown). There was no interference by various pituitary, pancreatic and gastrointestinal hormones as described elsewhere (Makino et al., 1977). The displacement curve of the gastric extracts was also seen to be parallel to the standard curve of gastrin, although extraction rate of gastrin in acetic acid was lower than that in water (data not shown). As shown in table 1, the gastric SRIF content of hypophysectomized rats decreased significantly compared with control rats. The SRIF content in hypophysectomized rats increased after the administration of bovine GH for 7 days to near control levels. In control rats SRIF content increased significantly after GH administration. In hypophysectomized rats, the gastrin content decreased, but after the administration of GH was restored to near control levels (Table 2) ${ }^{\circ}$ In control rats gastrin content increased after $\mathrm{GH}$ administration (Table 2). However, these changes in gastrin content were not significant. The body weight and stomch weight of hypophysectomized rats significantly decreased and were restored to control levels by the administration of bovine GH (Table 2). 


\section{Discussion}

The present study has shown that SRIF and gastrin content increased after $\mathrm{GH}$ administration and decreased after hypophysectomy. These changes in SRIF after hypophysectomy were consistent with our earlier work on the hypothalamus (Kanatsuka et al., 1979). In the hypothalamus, SRIF content per organ as well as per $\mathrm{mg}$ wet weight decreased significantly after hypophysectomy. On the other hand total SRIF content in the pancreas had not changed or decreased but its content per mg wet weight as well as per $\mathrm{mg}$ protein was markedly increased after hypophysectomy (Kanatsuka et al., 1977). The reason for this discrepancy remains to be determined. The result for SRIF after GH administration was compatible to the observation for the hypothalamus (Kanatsuka et al., 1979) and the pancreas (data was not shown). Although the changes in gastrin content of the stomch were not significant in the present study, our results were not inconsistent with the observation of Enochs et al. (Enochs and Johnson, 1976). Since it was reported that SRIF secretion in the gastric vein decreased after hypophysectomy (Yamamoto et al., 1979), it is possible that GH may affect SRIF secretion as well as its synthesis in the gastric $\mathrm{D}$ cells. In the hypothalamus we assumed that GH acted directly or indirectly through somatomedins on the somatonergic cell bodies, and increased the SRIF content (Kanatsuka et al., 1979). In the stomach it is also possible that $\mathrm{GH}$ acted directly or indirectly through somatomedins on gastric D cells as well as G cells, and increased the SRIF and gastrin content. Since this effect of endogenous GH was absent following hypophysectomy, it seemed likely that SRIF and gastrin content decreased in the hypophysectomized rats. Furthermore it was reported that hypophysectomy resulted in the atrophy of chief cells as well as parietal cells associated with decreased secretion (Schapiro et al., 1970; Crean, 1963: Snapper et al., 1937; Jacobson and Magnani, 1964). The atrophy of gastric mucosa was reversed by GH administration (Crean, 1963). These findings suggest that GH acts directly on chief cells as well as parietal cells. A second possibility is that GH acts first on gastric $G$ cells and this increased gastrin in turn affects the D cells as well as other cells. This is supported by reports that gastrin enhanced gastric SRIF release (Barden et al., 1979) and had a trophic effect on parietal cells (Johnson, 1974). A third possibility is that GH acts first on the parietal cells and causes acid secretion and this hyperacidity in turn affects the function of D cells and $\mathrm{G}$ cells. However, this is unlikely because hyperacidity inhibits gastrin secretion (Jordan and Garcia-Rinald, 1969), but stimulates SRIF secretion (Schusdziarra et al., 1978). It is also unlikely that GH acts first on D cells and that increased SRIF affects on other cells, because SRIF inhibits action of $\mathrm{G}$ cells and parietal cells.

Therefore it was suggested that $\mathrm{GH}$ affects $D$ cells directly or indirectly through the changes in $G$ cells' function.

\section{Acknowledgements}

We are grateful to NIAMDD for the donation of bovine GH. We wish to express our gratitude to Prof. Noboru Yanaihara, Shizuoka College of Pharmacy, for the donation of $\mathrm{N} \alpha$-tyrosyl somatostatin. We thank Prof. Kunio Okuda, First Department of Internal Medicine, Chiba University for helpful discussions and Miss Mutsuko Nishio for her excellent technical assistance.

\section{References}

Albinus, M., E. L. Blair, B. H. Hirst, J. D. Reed, A. V. Schally and B. Shaw (1977). The effects of somatostatin and metiamide on tachyphylaxis of pentagastrin stimulated gastric acid and pepsin 
secretion in the conscious cat. J. Physiol. 226.

Arimura, A., H. Sato, A. Dupont, N. Nishi and A. V. Schally (1975). Somatostatin: aboundance of immunoreactive hormone in rat stomach and pancreas. Science 189, 1007-1009.

Barden, N., A. Dupont and Jean-Pierre Côté (1979). Pentagastrin and adenosine $3^{\prime}, 5^{\prime}$-cyclic monophosphate stimulated secretion of somatostatin from perifused rat gastric mucosa. Life Sci. 24, 739-742.

Bloom, S. R., C. H. Mortimer, M. D. Thorner et al. (1974). Inhibition of gastrin and gastric acid secretion by growth hormone release inhibiting hormone. Lancet 2, 1106-1109.

Crean, G. P. (1963). The endocrine system and the stomach. Vitam. Horm. 21, 215-280.

Creutzfeldt, W., R. Arnold, C. Creutzfeldt et al. (1971). Gastrin and $G$ cells in the antral mucosa of patients with pernicious anemia, acromegaly and hyperthyroidism and in a Zollinger-Ellison tumor of the pancreas. Eur. J. Clin. Invest. 1, 361-479.

Enochs, M. R. and L. R. Johnson (1967). Effect of hypophysectomy and growth hormone on serum and antral gastrin levels in the rat. Gastroentero$\log y$ 70, 727-732.

Guenther, B., C. S. Michael and E. O. Oliver (1975). Somatostatin suppresses secretin and pancreatic exocrine secretion. Science 190, 163-164.

Jacobson, E. D. and T. J. Magnani (1964). Some effects of hypophysectomy on gastrointestinal function and structure. Gut 5, 473-479.

Johnson, L. R. (1974). Gut hormones on growth of gastrointestial mucosa. In: Endocrinology of the Gut. (W. Y. Chey and F. P. Brooks ed.) Charles B. Slack, Thorofare, N. J., pp. 163-177.

Jordan, P. H. and Garcia-Rinald P. (1969). Physiology of gastrin. Am. J. Surg. 117, 822-830.

Kanatsuka, A., H. Makino, Y. Matsushima, M. Yamamoto and A. Kumagai (1977). Increase of somatostatin concentration in rat pancreas after hypophysectomy, Endocrinol. Japon. 24 (4), 409412.
Kanatsuka, A., H. Makino, Y. Matsushima, M. Osegawa, M. Yamamoto and A. Kumagai (1979). Effect of hypophysectomy and growth hormone administration on somatostatin content in the rat hypothalamus. Neuroendocrinology 29 (3), 186-190.

Makino, H., A. Kanatsuka, Y. Matsushima, M. Yamamoto, A. Kumagai and N. Yanaihara (1977). Effect of streptozotocin administration on somatostatin content of pancreas and hypothalamus in rats. Endocrinol. Japon. 24 (3), 295-299.

Makino, H., Y. Matsushima, A. Kanatsuka, M. Yamamoto, A. Kumagai and M. Nishimura (1979). Changes in pancreatic somatostatin content in spontaneously diabetic mice, as determind by radioimmunoassay and immunohistochemical methods. Endocrinology 104, 243-247.

Polak, J. M., A. G. E. Pearse, L. Grimelius, S. R. Bloom and A. Arimura (1975). Growth hormone release inhibiting hormone (GH RIH) gastrointestinal and pancreatic D cells. Lancet 1, 1220 .

Schapiro, H., L. D. Wruble and L. G. Britt (1970). The effect of hypophysectomy on the gastrointestinal tract. A review of the literature. Am. J. Dig. Dis. 15, 1019-1030.

Schrumpf, E., M. H. Vatn, K. F. Hanssen, L. S. Semb and J. Myren (1976). Somatostatin inhibits insulin-stimulated gastrin release and gastric secretion of acid, pepsin, and intrinsic factor $(1 \mathrm{~F})$ in duodenal ulcer patients. Scand. J. Gastroenterol. 11, 517-520.

Schusdziarra, V., V. Harris, M. Conlon, A. Arimura and R. H. Unger (1978). Pancreatic and gastric somatostatin release in response to intragastric and intraduodenal nutrients and $\mathrm{HCl}$ in the dog. $J$. Clin. Invest. 62, 509-518.

Snapper, I., J. Groen and D. Hunter (1937). Achlorhydria, anemia and subacute combined degeneration in pituitary and gonadal insufficiency. $Q$. $J$. Med. 6, 195.

Yamamoto, T., V. Schusdziarra and R. H. Unger (1979). Pancreatic and gastric D cell function in hypophysectomized dogs. Endocrinology 104 (6), 1559-1562. 